\title{
The Analysis of Student Demonstration Actions Against RUU KUPH and RUU KPK: Between Critical and Narcissistic Attitudes
}

\author{
Ilham Syahrul Jiwandono ${ }^{1)}$, Itsna Oktaviyanti ${ }^{2)}$ \\ Primary Teacher Education Study Program Faculty of Teacher Training and Education Universitas \\ Mataram,Brawijaya Street No.22, Mataram,Nuda Tenggara Barat ${ }^{1,2)}$ \\ ilham_jiwandono@unram.ac.id ${ }^{1)}$, itsna@unram.ac.id ${ }^{2)}$
}

\begin{abstract}
Various policies issued by the legislative and executive bodies provoke various demonstrations carried out by students in various regions in Indonesia. This demonstration is a form of student attention in the sustainability of the Indonesian state. There are differences in the nuances of the demonstration that were conducted by students a few decades ago and now. The demonstration is now more a place for student narcissism. This study aims to analyze the students' critical and narcissistic attitudes in demonstrations. The research approach uses descriptive qualitative. Retrieval of data through interviews, observation and documentation. The research phase includes pre-field, field and data analysis. The location of the study was at the University of Mataram Elementary School Teacher Education Study Program. The data sources are students in the 3rd and 5th semester and lecturers at the University of Mataram, Elementary School Teacher Education Program. The results showed: (1) The demonstration was triggered by students' objections to the RUU KPK and the RUU KUHP. (2) Demonstrations bring positive and negative impacts for students. (3) There was a change in the nuances of the demonstration conducted by students. If all this time the demonstration was identical with the criticism of students, but now it has developed into a narcissism arena. (4). Student narcissism in demonstrations is based on their obsession to get recognition and appreciation from the community.

Keywords: demonstration, critical, narcissism
\end{abstract}

\begin{abstract}
Abstrak. Berbagai kebijakan yang dikeluarkan oleh lembaga legislatif dan eksekutif memancing berbagai aksi demonstrasi yang dilakukan oleh mahasiswa di berbagai daerah di Indonesia. Aksi demonstrasi ini merupakan wujud perhatian mahasiswa dalam keberlangsungan negara Indonesia. Terdapat perbedaan nuansa demonstrasi yang dilakukan mahasiswa beberapa dekade yang lalu dengan sekarang. Demonstrasi saat ini lebih banyak dijadikan ajang narsisme mahasiswa. Penelitian ini bertujuan untuk menganalisis sikap kritis dan narsis mahasiswa dalam aksi demonstrasi. Pendekatan penelitian menggunakan kualitatif deskriptif. Pengambilan data melalui wawancara, observasi dan dokumentasi. Tahap penelitian meliputi pra lapangan, lapangan dan analisis data. Lokasi penelitian di Program Studi Pendidikan Guru Sekolah Dasar Universitas Mataram. Sumber data yakni mahasiswa semester 3 dan 5 dan dosen Program Studi Pendidikan Guru Sekolah Dasar Universitas Mataram. Hasil penelitian menunjukkan: (1) Aksi demonstrasi dipicu oleh keberatan mahasiswa terhadap RUU KPK dan RUU KUHP. (2) Aksi demonstrasi membawa dampak positif dan negatif bagi mahasiswa. (3) Terjadi perubahan nuansa demonstrasi yang dilakukan oleh mahasiswa. Jika selama ini aksi demonstrasi identik dengan kekritisan mahasiswa, namun saat ini berkembang menjadi ajang narsisme. (4). Sikap narsisme mahasiswa dalam demonstrasi didasari oleh obsesi mereka untuk mendapatkan pengakuan dan penghargaan dari masyarakat
\end{abstract}

Kata Kunci: demonstrasi, kritis, narsis 


\section{INTRODUCTION}

Gejayan called, Bengawan resisted, Surabaya sued and many other actions throughout the country including in Malang, Mataram, and Kendari were proof that students paid more attention to the sustainability of this country. The students highlighted the performance of the board members, especially in the formulation of the draft legislative regulations resulting from discussions with the government. They simultaneously sued their representatives in parliament after the approval of the Criminal Code Bill and the KPK Bill. Both of these bills are considered to contain controversial articles that contradict the principles of justice and are contrary to the interests of the people. Students as agents of change do have the responsibility to defend the interests of the people. What they do is a natural thing because they are worried that the interests of the people will be oppressed by the interests of the authorities. The movement temporarily bore fruit by delaying its endorsement even though the ending of the demonstrations in the various regions ended in the majority of clashes between demonstrators and members of the police force. However, the focus of these actions was participants in the demonstration who had different objectives when acting. Some students know the substance of the bill so that their hearts are touched to take action. This critical attitude is reflected in the way they communicate when invited to various television stations that seem to be able to understand the article by article they are concerned about. The critical attitude possessed by students needs to be built to solve the various problems they face (Widiyowati, 2015). Critical thinking also needs to be held to answer the doubts between doctrine and policies issued (Haviz, 2009). On the other hand, not a few participants who only joined the action without knowing what the substance of the bill was just for the sake of existence in social networks. This is evidenced by the various posters they brought to the demonstration site which actually had nothing to do with the contents of the bill. The narcissistic attitude carried out by these students cannot be blamed considering the time spent by students is the teenage years who try to look attractive in order to get recognition from their environment (Engkus, et al, 2017). This event is unique to be investigated because the demonstrations that occur at this time are different from previous years. The student movement from time to time always brings a different nuance so this is interesting to study. The current demonstration is seen as not only synonymous with the criticism of students in opposing policies issued by the government but also becomes a narcissistic arena for students for their existence on social networks. Today, the winds of penetration of social media on the lives of students are getting tighter. There is no day in their lives without being in front of a digital screen to simply play games, chat on Facebook or WhatsApp. With 
their agile fingers in and out of every wilderness of cyberspace. In the corner of a campus room, a student is sitting sweetly alone while giggling at the behavior of his friends in cyberspace. Face-to-face-interaction that is so thick in traditional society has shifted to artificial communication through gadgets.

\section{RESEARCH METHODS}

This study uses a qualitative method. Data generated from qualitative research procedures in the form of written and oral words in the form of descriptive data from observations in the field. On the other hand, Moleong (2018) said that qualitative research is research that aims to understand phenomena about what is experienced by research subjects, for example, behavior and perception holistically in the form of descriptions in the form of words and language. The stages in this study include the pre-field stage, the field stage, and the data analysis stage. The location of the research is in the Elementary School Teacher Education Study Program, University of Mataram. Data sources are divided into two, namely primary and secondary data sources. Primary data sources are students in semesters 3 and 5 who take part in demonstrations and lecturers while secondary data sources are various documents obtained from the mass media and observations and documentation in the field. Data collection techniques using interviews, observation, and documentation. The data analysis technique uses the technique version of Miles and Huberman, that there are three lines of activity, namely data reduction, data presentation, and drawing conclusions or verification (Usman, 2009).

\section{DISCUSSION}

\section{Demonstrations and their impact on students}

In its history, not this time I am a student taking massive demonstrations. There are at least three large-scale demonstrations on behalf of students. In fact, two of them were able to subvert the ruling regime.

In everyday life, all people in this country, whether students, farmers, state officials, party leaders, or ordinary citizens, experience various problems in their daily lives. Problems that arise mainly for citizens, encourage them to make demands, protest, and support (aspirations and interests). Increased courage to express the wishes and ideas of community members as a consequence of a more dialogical and transparent political communication. Now community members are bolder and sharper in expressing their wishes to their leaders (Corry, 2009).

One form of protest and community demands is the action carried out by students some time ago. There are various controversial articles in the Criminal Code Bill and the KPK Bill which trigger students to launch their actions. These articles include issues related to abortion, corruption, insulting the president, adultery to the homeless. One of the articles in 
question is Article 432 of the Criminal Code concerning homelessness which states that anyone who is homeless on the street or in a public place that disturbs public order is liable to a maximum fine of 1 million. This article clearly contradicts the 1945 Constitution of the Republic of Indonesia which states that the poor and abandoned children are nurtured by the state. This is consistent with the results of interviews with students participating in the demonstration who said that homeless people should not be convicted because of their actions because they are included in state responsibility. The guest speaker continued that so far the government was still unable to overcome the homelessness problem. This is also in line with the opinion of Nusanto (2017) which says that currently the government is still unable to alleviate the homelessness problem.

Various demonstrations carried out by students have a big impact, both negative and positive impacts. Viewed from the positive side, the results of interviews with informants obtained information that the positive impact of the demonstration is the emergence of enthusiasm in conveying aspirations and having a high sense of solidarity among fellow demonstrators, although they do not know each other but the same goal is to convey aspirations for the benefit of the community. This was confirmed by the results of documentation in the field which showed that there were many participants who helped each other including preparing drinking water and food. Another speaker explained that the positive impact of participating in the demonstration was having a sense of pride in him for being given the opportunity to voice the aspirations of the people of Indonesia. He continued that taking part in demonstrations was a form of political participation other than through general elections.

In addition to the positive impacts, the demonstration also had many negative impacts, especially if the action led to riots. One of the biggest impacts if demonstrations lead to riots is economic instability. Many foreign investors think twice before investing in Indonesia. This is consistent with the results of interviews with informants who said that demonstrations that ended in riots would make the country unstable, especially in the economic field. The results of interviews with other informants obtained information that the negative impact of the demonstration is that it can trigger community tensions with state institutions, one of which is the DPR where the DPR should represent the interests of the people. Besides that, the demonstration also triggered tension between the participants and the police which could cause material losses that were not insignificant. Damage to public facilities and the fall of victims died or injured when the demonstration some time ago became evidence that the demonstration also had a large negative impact. Documentation results in the field show that many participants 
of the demonstration fell because of tear gas fired by the police. This was triggered by the actions of several individuals who tried to damage public facilities and tried to provoke the police.

\section{Critical Attitudes of Students in} Demonstration Acts Refusing the Criminal Code Bill and the KPK Bill

Wasisto and Prayudi (2019) explained that the main reason students held a demonstration was because of disagreement over issues that were considered strategic amid in blocked channels of state institutional communication with the public. The results of interviews with informants obtained information that students acknowledge this. During this time it seems as if there is a separation between the government institutions and the community. This has triggered the students' anger which led to demonstrations. One of the speakers explained that their reason for taking part in the demonstration was to want to demand justice because they objected to the rules made and considered the articles in the Criminal Code Bill to be unreasonable. The speaker continued that he took part in the demonstration as a form of participation in democracy to represent the people of Indonesia. Demonstrations are part of political participation. Political participation is a very important element in a democratic country, including Indonesia.
Demonstrations are also evidence of political modernization.

Another informant explained that he took part in the demonstration because he wanted to participate in the process of rejecting decisions that were not in accordance with the needs of the community. Furthermore, he said that the government should make regulations that can make people more advanced and prosperous. From the two opinions above it can be seen that students have a critical attitude towards the laws and regulations issued by the government. Field observations also showed that they enthusiastically expressed their aspirations in front of the West Nusa Tenggara Provincial Parliament building to meet with their representatives. This attitude deserves a thumbs up because it shows that students are one of the pillars of change. This critical attitude of students is aimed at the legislative and executive institutions as political policymakers and implementers. The above facts are in accordance with what was said by Hasse (2012) who said that student responses to various policies at the regional and central levels were very high. Demonstrations carried out by students as a form of control of state policies that are considered contrary to the interests of the people. Demonstrations conducted by students should not need to be a problem and even need to be appreciated as a form of alignments to the community. The critical attitude of students is very important 
for students to be rational in determining their choices (Widiyowati, 2015).

\section{The Phenomenon of Student Narcissistic} Attitudes in Demonstration Acts Refusing the Criminal Code Bill and the KPK Bill

The development of technology has brought a great impact on the life of the state. Marc Prensky (Maryani, 2016) in On the Horizon illustrates that the current generation is identical with the term 'digital-born from birth' (born-digital), the generation that is fluent in networking (net savvy). Not surprisingly, friendship with digital technology often seems far more familiar than friendship in the real world. Millennials are now the largest market share and consumer in media. This certainly affects students in social media life, including in relation to their demonstration. There was a change in the nuances of the demonstrations that were carried out by students from time to time. The critical attitude of students in demonstrations is not new. Since a few decades ago, one of the students' critical attitude was indeed implemented in the form of demonstrations.

However, what students have done some time ago is a new thing that is rarely found, namely narcissistic. One informant said he joined the demonstration because he only wanted to enliven it without knowing what substance was being aspired. They brought papers written with various writings that had nothing to do with the substance of the demonstration which they then uploaded to social media. This is supported by the fact that shows that social media is one of the media that supports narcissistic attitudes (Izzati and Irma, 2018). On the other hand, Davidson (2015) in his writing explained that social media is an online activity that is very popular with many people, with an average accessing 40 minutes per day. Besides, Mangold and Faulds (2009) explain that social media is very possible for someone to get answers directly to questions that arise and can be used as a media to obtain certain interests.

Narcissistic attitude possessed by students is a sign that they have a love of themselves and want to get the attention of others (Santi, 2017). The narcissism of students in demonstrations shows that humans always want to display their involvement in important events. The documentation results in the field also showed that many participants in the demonstration only took pictures in the middle of the demonstration and then uploaded it on their social media. What they do shows that the demonstration is only as a medium to channel personal pleasure. This is consistent with the opinion of Engkus, et al (2017) who say that someone who has a narcissistic tendency is more interested in things that smell of personal pleasure alone. Their narcissism during demonstrations can indicate that they received less attention in their childhood. This is consistent with the opinion of Halgin and Whitbourne (2010) which explains that 
someone who tends to have narcissistic habits is based on the lack of attention in childhood.

Student narcissism during demonstrations also shows that they have an obsession to become someone who has a superior position by following various important events that occur in society. The results of interviews with informants obtained information that they brought posters that had nothing to do with the sub-demonstration just because they wanted to show their existence and wanted to get recognition, admiration, and appreciation from others.

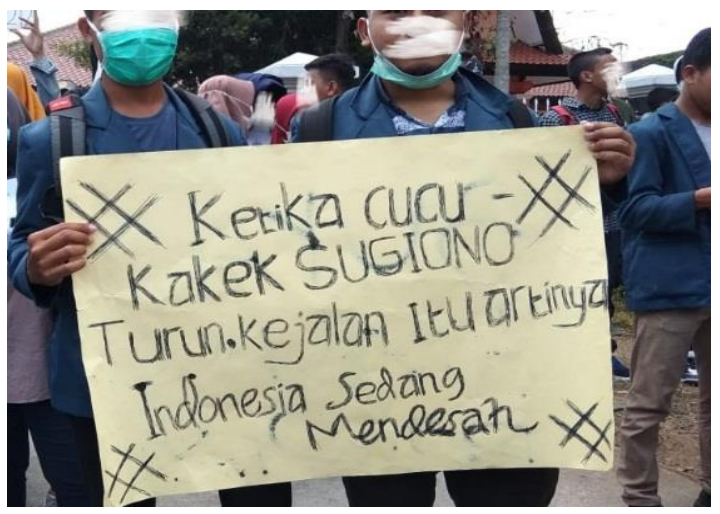

Picture 1. Posters brought by the demonstrators

Student narcissism is not necessarily blamed because adolescence is a time to actualize itself through existence in various events, including demonstrations. Their existence is usually channeled through social media, including demonstrations. However, it should be underlined that not always narcissism has a positive impact, including narcissistic attitudes carried out in demonstrations. The documentation shows that there are students who are involved in the problem because they carry posters that are considered too excessive and violate the norms of politeness that disturb the comfort of the community. This shows that narcissistic attitude is also a personality disorder caused by expectations that are too high to get appreciation but through a wrong thought process. The interview results show that narcissistic attitudes are common and need not be questioned. But the problem is if the narcissism is disturbing the peace of others. In this condition, narcissists need to get serious handling. After all, it has been indicated to be in a worse direction because it disturbs the comfort of others. One way to handle it is by using psychological therapy (Engkus, 2017). The results of interviews with informants obtained information that they prepared posters all night to get the perfect poster to expect high recognition.

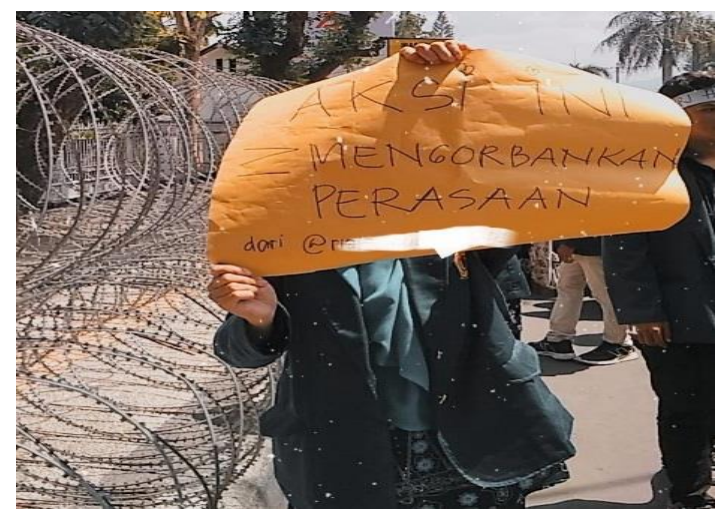

Picture 2. Posters brought by the demonstrator accompanied by instagram account

This can be a problem because when someone is trapped into thinking that everything must be perfect, including 
narcissism, it will affect his life. The impact, relationships with others can be problematic. If allowed to continue, it will create confusion for themselves and others because they feel disturbed and in the end will make them shunned and automatically their needs in social interaction will be disrupted.

\section{CONCLUSION}

Demonstrations by students were triggered by their dissatisfaction with the Criminal Code Bill and the Corruption Eradication Commission Bill initiated by the Parliament and the government. Many students oppose this regulation because it is considered contrary to the interests of the people. Demonstrations by students have positive and negative impacts. The positive impact is that the aspirations of people who object to the two regulations are conveyed.

Besides, the demonstration also showed that students were able to play their role as agents of change. While the negative impact is the instability, especially in the economic field and the fall of many victims, both fatalities and injuries, and many public facilities that were damaged. The students 'critical attitude in the demonstration should be appreciated because of the students' attention to the interests of the community. A critical attitude also needs to be developed in students as a form of social control over state institutions, both executive and legislative institutions.
There has been a change in the phenomenon of demonstrations conducted by students in the last few years. If in the past the demonstration was identical to the student's critical attitude, but now it is also a student narcissistic event. Many students took part in the demonstration but did not know what substance was aspired. This is evidenced by the large number of students carrying posters that have nothing to do with demonstrations for their existence on social media. What is done by these students is a natural thing because they have an obsession to get recognition and appreciation from others.

\section{REFERENCES}

[1] Corry, Andi W. (2009). Etika Berkomunikasi dalam Penyampaian Materi. Jurnal Komunikasi Universitas Tarumanagara, 1(1)

[2] Davidson, L. (2015). Is your daily social media usage higher than average? - Telegraph. Online].Available from: http://www.telegrap h.co.uk/finance/newsbysector/mediatechnolo gyan dtelecoms/11610959/Is-your-dailysocial-media-usage-higher-thanaverage.html. Diakses 15 Januari 2020.

[3] Engkus, dkk. (2017). Perilaku Narsis Pada Media Sosial Di Kalangan Remaja Dan Upaya Penanggulangannya. Jurnal Penelitian Komunikasi, 20 (2).

[4] Halgin, R.P. \& Whitbourne, S.K. (2010). Psikologi Abnormal. Jakarta: Salemba Humanika

[5] Hasse, J. (2012). Anarkisme Demonstrasi Mahasiswa: Studi Kasus Pada Universitas Islam Negeri Alauddin Makassar. Jurnal Studi Pemerintahan, 3(1).

[6] Haviz, Muhammad. (2009). Berpikir Dalam Pendidikan: (Suatu Tinjauan Filsafat Tentang Pendidikan Untuk Berpikir Kritis). Jurnal Ta'dib, 12(1). 
[7] Husaini, Usman. (2009). Metodologi Penelitiam Sosial. Jakarta : Bumi Aksara

[8] Izzati, Fadhila dan Ade Irma. (2018). Perilaku Narcissistic Pada Pengguna Instagram Di Kalangan Mahasiswa Universitas Serambi Mekkah. Jurnal Ilmiah Mahasiswa FISIP Unsyiah, 3(2).

[9] Mangold, W.G. \& Faulds, D.J. (2009). Social Media:The New Hybrid Element of T he Promotion Mix. Business Horizons, 52 (4 )

[10] Maryani, Eri. (2016). Peningkatan Kualitas Layanan Perpustakaan untuk Digital Native Generation (Perspektif Perubahan Karakter Pemustaka di Era Digital), Prosiding Seminar Nasional Komunikasi, Universitas Lampung.

[11] Moleong, Lexy J. (2018). Metode Penelitian Kualitatif, cetakan ke-37. Bandung : PT. Remaja Rosdakarya

[12] Nusanto, Baktiawan. (2017). Program Penanganan Gelandangan Dan Pengemis Di Kabupaten Jember (Handling Programs Of Homeless And Beggar) In Jember District). Jurnal Politico, 17(2).

[13] Santi, Novi Nitya. (2017). Dampak Kecenderungan Narsiscisme Terhadap Self Esteem Pada Pengguna Facebook Mahasiswa PGSD UNP. Jurnal Dimensi Pendidikan dan Pembelajaran, 5(1).

[14] Wasisto, Aryo dan Prayudi. (2019). Gerakan Mahasiswa Dan Upaya Mengurai Tuntutan. Buletin Info Singkat, 11 (19)

[15] Widiyowati, Iis Intan. (2015). Hubungan Kemampuan Berpikir Kritis Dengan Respon Mahasiswa Terhadap Penggunaan Model Pembelajaran Advance Organizer Pada Materi Larutan Penyangga. Jurnal Pancaran, 4(1). 